\title{
Genetic variability of the Brazilian hair sheep breeds
}

\author{
Samuel Rezende Paiva( ${ }^{(1)}$, Vanessa Chaves Silvério ${ }^{(2)}$, Andréa Alves Egito(1), Concepta McManus ${ }^{(2)}$, \\ Danielle Assis de Faria( ${ }^{(3)}$, Arthur da Silva Mariante ${ }^{(1)}$, Sílvia Ribeiro Castro(1), \\ Maria do Socorro Maués Albuquerque ${ }^{(1)}$ and Jorge Abdala Dergam ${ }^{(4)}$
}

\begin{abstract}
(1)Embrapa Recursos Genéticos e Biotecnologia, CEP 70770-900 Brasília, DF, Brazil. E-mail: samuel@cenargen.embrapa.br, vanessa@cenargen.embrapa.br, egito@cenargen.embrapa.br, mariante@cenargen.embrapa.br, silvia@cenargen.embrapa.br, maues@cenargen.embrapa.br (2)Universidade de Brasília, Fac. de Agronomia e Veterinária, CEP 70910-900 Brasília, DF, Brazil. E-mail: concepta@unb.br (3)Universidade Federal de Viçosa (UFV), Dep. de Zootecnia, CEP 36571-000 Viçosa, MG, Brazil. E-mail: danyaf@homenet.com.br (4)UFV, Dep. de Biologia Animal, CEP 36571-000 Viçosa, MG, Brazil. E-mail: dergam@ufv.br
\end{abstract}

Abstract - The objectives of this work were to investigate the genetic structure of the Brazilian hair sheep breeds and to determine the origin of the Santa Inês breed. Molecular similarity was determined using Randomly Amplified Polymorphic DNA - Polymerase Chain Reaction markers in 238 individuals from five naturalized sheep breeds: Santa Inês (48 animals), Rabo Largo (48), Somali (48), Morada Nova (48) and Bergamasca (46), collected in Goiás, Sergipe, Bahia, and Ceará States as well as in the Federal District. Fifty-four loci were selected from 19 primers, after a pilot test using 140 primers. Qualitative analyses indicate diagnostic markers for all breeds. All breeds were significantly different from each other. Interbreed differences were explained by $14.92 \%$ of the total variation. Santa Inês clustered with Bergamasca (97\% bootstrap) and with Rabo Largo, composing the third member of the group (81\% bootstrap) while Morada Nova and Somali breeds clustered separately. Each breed should be considered as a separate management and conservation unit, and special care should be taken with Rabo Largo, Morada Nova and Somali breeds, represented by small herds in Brazil.

Index terms: Ovis aries, conservation genetics, domestic animal diversity, molecular markers, RAPD.

\section{Variabilidade genética de raças de ovelhas deslanadas do Brasil}

Resumo - Os objetivos deste trabalho foram identificar a origem racial de ovinos Santa Inês e avaliar a unicidade das populações das principais raças naturalizadas brasileiras de ovinos deslanado. Foi realizado um estudo dos padrões de semelhança molecular a partir de marcadores RAPD-PCR, utilizando-se 238 indivíduos dos Estados de Goiás, Sergipe, Bahia, e Ceará assim como do Distrito Federal, distribuídos entre as raças Santa Inês (48 animais), Bergamácia (46), Rabo Largo (48), Morada Nova (48) e Somali (48). Após triagem com 140 primers, foram selecionados 54 locos a partir de 19 primers e todas as raças apresentaram marcadores específicos. Análises qualitativas mostraram a presença de marcadores diagnóstico-específicos para todas as raças. As diferenças inter-raciais foram significativas e responsáveis por 14,92\% da variação total observada. Na análise de agrupamento, a raça Santa Inês ficou próxima à Bergamácia (com 97\% de valor bootstrap). A raça Rabo Largo apresentou maior similaridade com este grupo (com 81\% bootstrap) do que as raças Morada Nova e Somali. Cada raça deve ser considerada como unidade de conservação e manejo, especialmente as raças Rabo Largo, Morada Nova e Somali, as quais apresentam as menores populações no País.

Termos para indexação: Ovis aries, genética da conservação, diversidade de animais domésticos, marcadores moleculares, RAPD.

\section{Introduction}

Sheep husbandry has been traditionally considered as of low commercial value in Brazil, and it is generally restricted to the informal economy. According to the Morais (2000), these practices determined that Brazilian sheep products such as wool, meat and hides, were uncompetitive compared to other countries, which invested in genetic improvement of production traits and conservation of national breeds. In the Northeast and Central West of Brazil, regions characterized by long dry periods, hair sheep breeds represent an important source of protein for local populations. More recently, in these regions, market diversification has increasingly 
considered sheep as a viable and lucrative option. However, efforts for closure of genealogical registers and crossbreeding actions have been hampered by the lack of data of the genetic structure of breeds.

The first strategic step is, therefore, to increase knowledge of existing genetic variability among the main breeds of Brazilian hair sheep, and to identify their breed origins. RAPD-PCR molecular markers - Random Amplified Polymorphic DNA - Polymerase Chain Reaction (Williams et al., 1990), when applied with criteria (Black, 1993), are used as a preliminary approach to identify possible patterns of inter- and intra-population genetic variation. This allows the application of conservation programs on threatened or endangered species (Cardoso et al., 1998). Few RAPD studies are available on sheep populations (Kantenen et al., 1995; Yuanfang et al., 2002; Ali, 2003).

The objectives of this work were to characterize the genetic structure of five Brazilian hair sheep breeds using RAPD-PCR molecular markers and to determine the origin of Santa Inês breed.

\section{Material and Methods}

\section{Sample collection and DNA extraction}

Blood was collected from 238 individuals of Santa Inês, Morada Nova, Somali, Rabo Largo and Bergamasca breeds in Goiás, Sergipe, Bahia and Ceará States as well as in the Federal District. DNA was extracted from leucocytes using an inorganic protocol modified by Miller et al. (1988). After extraction the DNA was diluted ( $3 \mathrm{ng} \mu \mathrm{L}^{-1}$ ), quantified by spectrophotometer and in agar gel at $1 \%$ and stored at $-20^{\circ} \mathrm{C}$ until use.

\section{RAPD-PCR Analysis}

The PCR reactions were carried out in a MJ Research (PTC100) thermocycler using an amplification program with 40 cycles in the following stages: a) $15 \mathrm{sec}$ at $94^{\circ} \mathrm{C}$, b) $1 \mathrm{~min}$ at $35^{\circ} \mathrm{C}$ and c) $1 \mathrm{~min}$ at $72^{\circ} \mathrm{C}$. At the end of the 40 cycles, an additional stage of $7 \mathrm{~min}$ at $72^{\circ} \mathrm{C}$ was added for complete extension of amplified products. RAPD-PCR reactions were carried out in a final volume of $13 \mu \mathrm{L}$, with $20 \mathrm{mM}$ Tris-HCl (pH 8.4); $50 \mathrm{mM}$ $\mathrm{KCl} ; 3.5 \mathrm{mM} \mathrm{MgCl} \mathrm{M}_{2} ; 200 \mu \mathrm{M}$ of each dNTP; 8\% BSA $2.5 \mathrm{mg} \mathrm{mL}^{-1} ; 0.4 \mu \mathrm{M}$ of the arbitrary primer; 1.5 U Taq DNA polymerase (Phoneutria Biotechnology

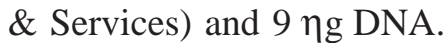

A total of 140 decamer oligonucleotide primers (Operon Technologies Inc., Alameda, Calif., kits: A, B,
$\mathrm{J}, \mathrm{K}, \mathrm{N}, \mathrm{S}$ and $\mathrm{AB}$ ) were screened using on DNA from all breeds. Primers were designated as useful if they yielded well-amplified, distinguishable polymorphic bands.

Data were recorded in a binary matrix ( 1 = presence of a band, $0=$ absence). Before analyses were carried out, fragments with a frequency higher than 1- (3/N) (in which $\mathrm{N}$ is the population sample), in each population were discarded, to avoid biased estimate of allele frequencies (Lynch \& Milligan, 1994). Allelic frequency was estimated for the null allele (absence of fragment) using the formula proposed by Lynch \& Milligan (1994) for unbiased samples:

$\hat{\mathrm{q}}=\hat{\mathrm{x}}^{\frac{1}{2}}\left[1-\frac{\frac{\hat{\mathrm{x}}(1-\hat{\mathrm{x}})}{\mathrm{N}}}{8 \hat{\mathrm{x}}^{2}}\right]^{-1}$,

where $\hat{\mathrm{q}}$ is the estimated null allele frequency, $\hat{\mathrm{x}}$ is the proportion of the $\mathrm{N}$ sampled individuals that do not exhibit the marker.

Within-breed gene diversity was estimated from expected heterozygosis $(\mathrm{H})$ under Hardy-Weinberg equilibrium, and the proportion of polymorphic loci (P). Bands were screened as "diagnostic" when they were unique for some breeds, and as "characteristic" when they occurred in up to 5\% of individuals of other breeds. Genetic structure was estimated with Fisher's Exact Test (Raymond \& Rousset, 1995) under null hypothesis of panmixis. Hierarchical analysis was conducted with AMOVA (Huff et al., 1993). Nei's distance with correction of Lynch \& Milligan (1994) was used to determine among population and breed variability, which was depicted as a neighbor joining (NJ) phenogram and bootstrap analysis with 1000 repetitions.

Genetic similarity among all individuals was estimated using Jaccard's coefficient, which was also used for principal component analysis. This analysis is preferred because phenotypic data are complex and do not allow over-laying of operational taxonomic units (OTUs) in hierarchical grouping studies (De Queiroz \& Good, 1977).

Genetic variability within and between populations was estimated using TFPGA - Tools for Population Genetics Analysis (Miller, 1997), RAPDDIST (West \& Black, 1998) and PHYLIP 3.5 (Felsenstein, 1993). Analyses of molecular variance were carried out using Arlequin (Schneider et al., 2000), and NTSYS-pc (Numerical Taxonomy and Multivariate Analysis System) 2.0 (Exeter Software, Setauked, N.Y.) was used for principal component analysis. 


\section{Results and Discussion}

Nineteen primers (OPA10, OPB11, OPB19, OPB20, OPK01, OPK02, OPN03, OPN05, OPN11, OPN15, OPN19, OPN20, OPS02, OPS04, OPS05, OPS10, OPS18, OPAB04, OPAB11, OPERON Technologies, Inc.) were selected for DNA amplifications from 238 individuals. Fifty-four bands (loci) represented by conspicuous and reproducible fragments were selected. The size of the bands varied from 339 to 2,536 base pairs.

Within each breed, calculations showed that Somali had lowest values and Rabo Largo had highest for expected heterozygosis $(\mathrm{H})$ (Table 1), while Santa Inês showed highest proportion of polymorphic loci (P) levels. These values were higher within breeds than between breeds. Within population values for $\mathrm{H}$ and $\mathrm{P}$ were highest in Rabo Largo from EBDA and lowest in Somali and Bergamasca from Goiás. Considering that Bergamasca from Goiás was also the smallest analyzed group, sampling errors could not be discarded.

Qualitative analysis of band frequencies (Table 2) showed that Santa Inês and Morada Nova had diagnostic loci when compared to all other breeds, but not between each other. On the other hand, low $\mathrm{H}$ and $\mathrm{P}$ indices and high levels of differentiation that characterized Somali were independently confirmed by the presence of diagnostic and characteristic loci of other breeds, compared to Somali. These results indicate that, due to processes of genetic drift and endogamy, Somali has

Table 1. Gene diversity $(\mathrm{H})$ and percentage of polymorphic loci $(\mathrm{P})$ at the population $\left(\mathrm{H}_{\mathrm{pop}}, \mathrm{P}_{\mathrm{pop}}\right)$ and breed $\left(\mathrm{H}_{\text {breed }}, \mathrm{P}_{\text {breed }}\right)$ level for the 238 Brazilian hair sheep individuals evaluated.

\begin{tabular}{llcccc}
\hline Population $^{(1)}$ & $\mathrm{N}^{(2)}$ & $\mathrm{H}_{\text {pop }}$ & $\mathrm{P}_{\text {pop }}$ & $\mathrm{H}_{\text {breed }}$ & $\mathrm{P}_{\text {breed }}$ \\
\hline OSI CO & 15 & 0.3639 & 92.59 & & \\
OSI SE & 17 & 0.3799 & 90.74 & 0.3881 & \multirow{2}{*}{100} \\
OSI EM & 16 & 0.3592 & 87.04 & & \\
\hline OB DF & 33 & 0.3472 & 92.59 & \multirow{2}{*}{0.3857} & \multirow{2}{*}{98.15} \\
OB GO & 13 & 0.3735 & 85.20 & & \multirow{2}{*}{0.15} \\
\hline ORL EB & 28 & 0.4000 & 96.30 & \multirow{2}{*}{0.4050} & \multirow{2}{*}{0.15} \\
ORL JU & 20 & 0.3771 & 94.44 & & \multirow{2}{*}{04.44} \\
OMN VE & 23 & 0.3848 & 90.74 & \multirow{2}{*}{0.3929} & \multirow{2}{*}{0.74} \\
\hline OS BR & 25 & 0.3530 & 88.89 & & 90.7429 \\
\hline
\end{tabular}

(1)OSI CO: Santa Inês of Central West; OSI SE: Santa Inês of farms in Sergipe State; OSI EM: Santa Inês of Embrapa Tabuleiros Costeiros in Sergipe State; OB DF: Bergamasca of Universidade de Brasília, Federal District; OB GO: Bergamasca of farms in Goiás State; ORL EB: Rabo Largo of EBDA (Empresa Baiana de Desenvolvimento Agrícola); ORL EB: Rabo Largo of farms in Bahia State; OMN VE: Morada Nova (Red Line) of Embrapa Caprinos, Ceará State; OMN BR: Morada Nova (White Line) of Universidade Federal do Ceará, Ceará State; OS: Somali of Embrapa Caprinos, Ceará State. ${ }^{(2)}$ Sample sizes. been affected by stochastic events. The presence of diagnostic and characteristic bands between breeds will be useful in breeding conditions and conservation programs in these animals, as they can be used for breed identification in practical situations, such as crossbreeding recommendations and recognition of hybrids.

All breeds were significantly different from each other at $\mathrm{p}<0.001$ (Fisher's Exact Test). This also held among all populations except for three combinations of Santa Inês [Santa Inês from Central West - Santa Inês from Sergipe ( $=0.147)$; Santa Inês from Central West Santa Inês from Embrapa Tabuleiros Costeiros $(p=0.032)$; Santa Inês from Embrapa Tabuleiros Costeiros - Santa Inês from Sergipe $(p=0.012)$ ]. Differences were not significant between Santa Inês from Sergipe and Rabo Largo from EBDA ( $=0.081)$. Santa Inês was the only breed without significant differences between subpopulations due to the fact that at least some rams of the Central-West region are related to animals from Sergipe. The other two populations, Santa Inês from Sergipe and Santa Inês from Embrapa Tabuleiros Costeiros, are geographically closer and therefore more homogeneous. Additionally, crosses between Santa Inês and Suffolk have been carried out in the Northeast to improve rear-end conformation and these animals were registered as purebred Santa Inês. To test this hypothesis, codominant markers as well as Suffolk animals must be added in future analysis. Yuanfang et al. (2002) found that the genetic relationship between different indigenous and imported sheep breeds in China by RAPD markers was in accordance with their localities and breeding history, which indicated that the RAPD technique was sensitive to differentiate sheep breeds. Similarly, Ali (2003), studying four sheep breeds in Egypt, found more genetic similarity among indigenous breeds than commercial ones.

Interbreed differences accounted for $14.92 \%$ of total variation $(p<0.001)$ (Table 3$)$. Contrary to genetic variability levels detected in other naturalized Brazilian species, in which levels of $29.96 \%$ (Spritze et al., 2003) to $25.28 \%$ (Serrano et al., 2004) were found for cattle,

Table 2. Number of characteristic (up to 5\% presence; above diagonal) and diagnostic (specific; below diagonal) loci between five Brazilian hair sheep breeds.

\begin{tabular}{lccccc}
\hline & $\begin{array}{c}\text { Santa Inês } \\
(\mathrm{OSI})\end{array}$ & $\begin{array}{c}\text { Bergamasca } \\
(\mathrm{OB})\end{array}$ & $\begin{array}{c}\text { Rabo Largo } \\
(\mathrm{ORL})\end{array}$ & $\begin{array}{c}\text { Morada Nova } \\
(\mathrm{OMN})\end{array}$ & $\begin{array}{c}\text { Somali } \\
(\mathrm{OS})\end{array}$ \\
\hline OSI & - & $2 \mathrm{OB}$ & $1 \mathrm{ORL}$ & - & 3 OSI \\
OB & 1 OSI & - & - & $1 \mathrm{OB}$ & 4 OB \\
ORL & 1 OSI & - & - & $1 \mathrm{ORL}$ & 4 ORL \\
OMN & - & $1 \mathrm{OMN}$ & $1 \mathrm{OMN}$ & - & $3 \mathrm{OMN}$ \\
OS & $1 \mathrm{OSI}$ & $1 \mathrm{OS} / 2 \mathrm{OB}$ & $1 \mathrm{OS} / 2 \mathrm{ORL}$ & $2 \mathrm{OMN}$ & - \\
\hline
\end{tabular}


$24.53 \%$ for horses (Fuck, 2002), and $21.21 \%$ for goats (Oliveira, 2003), data found indicate that sheep have lower molecular variance. This relatively low value shows a close relationship between naturalized Brazilian sheep breeds, which are due to random crossbreeding between breeds at some time in history, associated with genetic drift. These breeds are descendant from a few European or African breeds (Mason, 1980), with a common evolution history. Alternatively, low levels of genetic variability, by these results, are indigenous to all sheep breeds analyzed. Kantenen et al. (1995), using RAPD markers, also found low genetic variability between two sheep breeds in Finland. Nevertheless, using data obtained from the mitochondrial DNA control region (mtDNA) from various breeds of short and fattailed European sheep, Tapio \& Grigaliunaite (2002) observed a higher level (27.84\%) of inter-breed differences.

Evidence shows a significant genetic structure of populations within breeds (Table 3 ), as the difference between populations of the same breed $(9.27 \%, \mathrm{p}<0.01)$ was similar to the variation between breeds $(9.54 \%$, $\mathrm{p}<0.01$ ). This result shows a low migration rate or exchange of animals between herds of the same breed. On the other hand, these results are important for management of these breeds, as the populations of the Morada Nova, Bergamasca and Rabo Largo behave as if they were independent management units.

The percentage of variation between the five breeds

Table 3. Analysis of molecular variance for 238 individuals sampled from five Brazilian hair sheep breeds ${ }^{(1)}$.

\begin{tabular}{lrrccc}
\hline Source of variation & Df & \multicolumn{1}{c}{ SS } & VC & Total (\%) & P-value \\
\hline Between breeds & 4 & 349.381 & 1.63875 & 14.92 & $<0.01$ \\
Within breeds & 233 & $2,177.652$ & 9.34615 & 85.08 & $<0.01$ \\
\hline Between breeds & 4 & 349.381 & 1.04837 & 9.54 & $<0.01$ \\
Between populations & 5 & 144.276 & 1.01820 & 9.27 & $<0.01$ \\
within breeds & & & & & \\
Within populations & 228 & $2,033.377$ & 8.91832 & 81.19 & $<0.01$ \\
\hline
\end{tabular}

${ }^{(1)} \mathrm{Df}$ : degrees of freedom; SS: sum of squares; VC: variance components. studied (Table 4), as well as between the ten populations of these breeds (Table 5), shows that the Rabo Largo is closer to the Santa Inês than to Morada Nova. The results also imply that Santa Inês resulted from a cross between wool and hair breeds, as it is close to both types of sheep included in the study. According to Morais (2001), the Santa Inês is a breed originated from crosses of Bergamasca with Morada Nova and Criollo sheep. The introduction of Bergamasca into Brazil occurred at the beginning of the $20^{\text {th }}$ century (Boletim Pecuário, 2004), and it was also the only wool breed used in the study. More wool breeds need to be included, as well as more molecular markers and animals to test the effects of sampling errors and bias estimations on the results. Among all breeds, Somali showed highest level of differentiation.

In some cases, the variation among populations within the same breed was higher than that with the population of another breed. Bergamasca from Goiás was closer to Santa Inês from Sergipe, Santa Inês Embrapa Tabuleiros Costeiros and Rabo Largo from EBDA than the Bergamasca from Universidade de Brasilia. Rabo Largo from EBDA was also closer to Santa Inês from Sergipe than to Rabo Largo from Juazeiro. Once again the Somali breed was placed apart from all other populations.

The phenetic dendrogram in Figure 1A is consistent with data in Table 4, showing greater proximity of Santa

Table 4. Percentage difference between five Brazilian hair sheep breeds estimated by analysis of molecular variance.

\begin{tabular}{lccccc}
\hline & $\begin{array}{c}\text { Santa Inês } \\
(\mathrm{OSI})\end{array}$ & $\begin{array}{c}\text { Bergamasca } \\
(\mathrm{OB})\end{array}$ & $\begin{array}{c}\text { Rabo Largo Morada Nova } \\
(\mathrm{ORL})\end{array}$ & $\begin{array}{c}\text { Somali } \\
(\mathrm{OMN})\end{array}$ & $(\mathrm{OS})$ \\
\hline OB & 6.82 & - & - & - & - \\
ORL & 5.93 & 11.08 & - & - & - \\
OMN & 10.47 & 14.40 & 5.12 & - & - \\
OS & 22.44 & 28.32 & 22.83 & 18.93 & - \\
\hline
\end{tabular}

Table 5. Percentage difference between populations from five Brazilian hair sheep breeds estimated by analysis of molecular variance $^{(1)}$.

\begin{tabular}{|c|c|c|c|c|c|c|c|c|c|}
\hline & OSI CO & OSI SE & OSI EM & OB DF & OB GO & ORL EB & ORL JU & OMN VE & OMN BR \\
\hline OSI SE & 6.24 & - & - & - & - & - & - & - & - \\
\hline OSI EM & 7.20 & 7.37 & - & - & - & - & - & - & - \\
\hline OB DF & 10.48 & 11.73 & 12.60 & - & - & - & - & - & - \\
\hline ORL EB & 9.48 & 3.51 & 6.87 & 12.03 & 13.87 & - & - & - & - \\
\hline ORL JU & 15.07 & 13.84 & 10.78 & 17.18 & 23.32 & 5.73 & - & - & - \\
\hline OMN VE & 18.53 & 11.77 & 16.53 & 19.65 & 20.67 & 7.32 & 8.98 & - & - \\
\hline OMN BR & 17.48 & 12.33 & 19.73 & 21.71 & 19.33 & 7.94 & 16.80 & 13.58 & - \\
\hline OS & 23.10 & 22.70 & 30.58 & 31.32 & 31.00 & 22.20 & 28.90 & 25.93 & 19.61 \\
\hline
\end{tabular}

(1)OSI CO: Santa Inês of Central West; OSI SE: Santa Inês of farms in Sergipe State; OSI EM: Santa Inês of Embrapa Tabuleiros Costeiros in Sergipe State; OB DF: Bergamasca of Universidade de Brasília, Federal District; OB GO: Bergamasca of farms in Goiás State; ORL EB: Rabo Largo of EBDA (Empresa Baiana de Desenvolvimento Agrícola); ORL EB: Rabo Largo of farms in Bahia State; OMN VE: Morada Nova (Red Line) of Embrapa Caprinos, Ceará State; OMN BR: Morada Nova (White Line) of Universidade Federal do Ceará, Ceará State; OS: Somali of Embrapa Caprinos, Ceará State. 


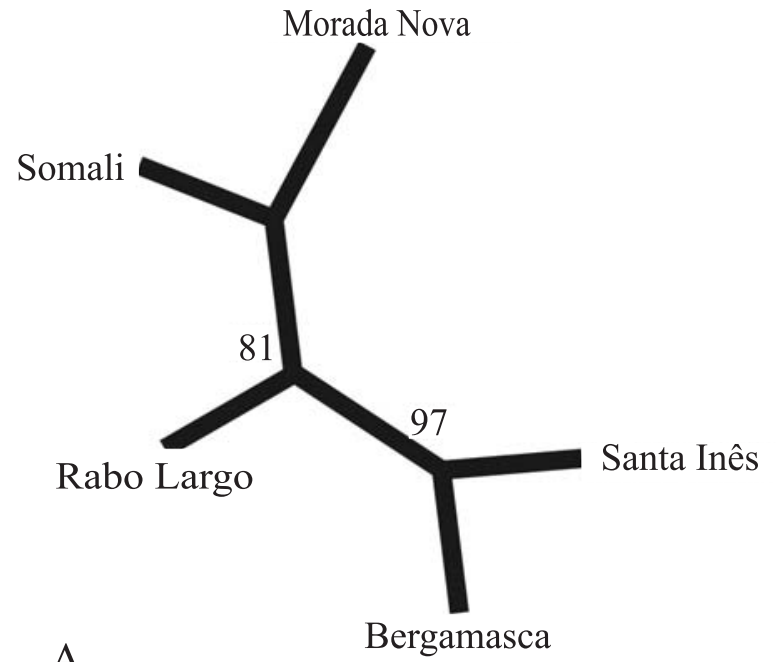

A

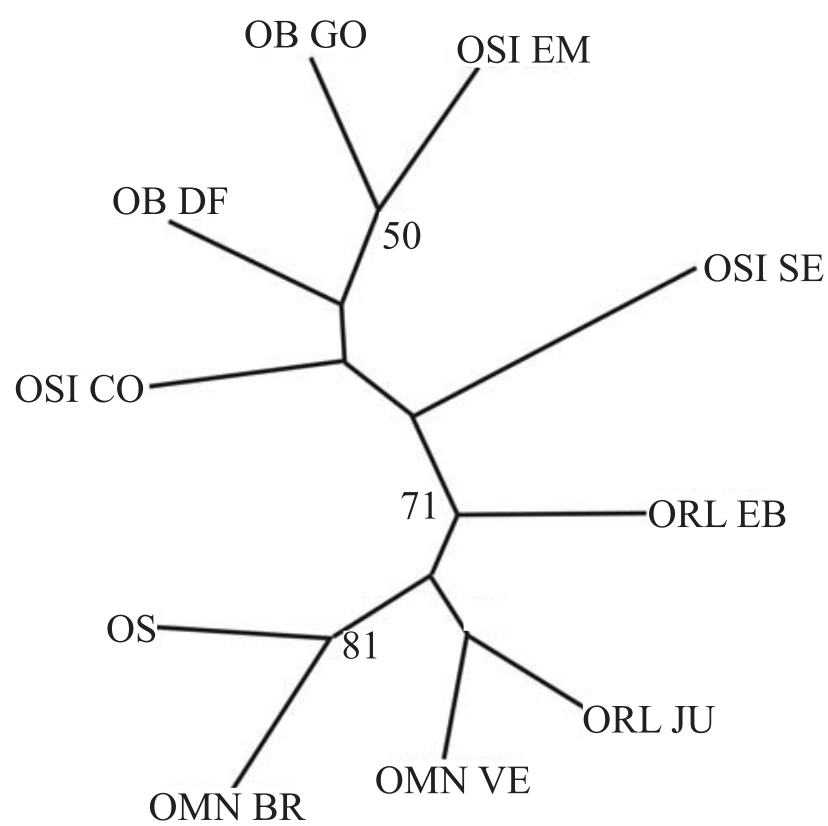

B

Figure 1. Dendrogram generated from Nei's distance and neighbor-joining grouping showing relationships between breeds (A) and populations (B) of Brazilian hair sheep. Only bootstrap values $>50 \%$ are shown. OSI CO: Santa Inês of Central West; OSI SE: Santa Inês of farms in Sergipe State; OSI EM: Santa Inês of Embrapa Tabuleiros Costeiros in Sergipe State; OB DF: Bergamasca of Universidade de Brasília, Federal District; OB GO: Bergamasca of farms in Goiás State; ORL EB: Rabo Largo of EBDA (Empresa Baiana de desenvolvimento Agrícola); ORL EB: Rabo Largo of farms in Bahia State; OMN VE: Morada Nova (Red Line) of Embrapa Caprinos, Ceará State; OMN BR: Morada Nova (White Line) of Universidade Federal do Ceará, Ceará State; OS: Somali of Embrapa Capinos, Ceará State.
Inês to Bergamasca (with 97\% of bootstrap support), as well as greater proximity of Rabo Largo to the former instead of Morada Nova ( $81 \%$ bootstrap). The dendrogram in Figure 1B shows that there is one group formed by the Santa Inês and Bergamasca populations and other by the remaining hair sheep. It is also evident that Santa Inês has a mixed origin from both wool and hair sheep, reflected on the intermediate position of Santa Inês from Sergipe between the two main groups (Figure $1 \mathrm{~B}$ and Table 5). In contrast, few clusters showed high bootstrap support in Figure 1B. This indicates that RAPD markers were unsuitable for resolving the relationships between populations of some breeds, but it shows that there was low genetic divergence between breeds. These results are corroborated by those in Table 5. Another explanation is the high rate of absorbent crosses carried out by sheep breeders who, looking for fast profits, use crossbreeding with wool meat breeds without maintaining stocks of purebred naturalized breeds.

Principal component analysis tested the consistency of results shown in the dendrograms (Figure 2). The first three principal components explain $56.47 \%$ of the total variation between animals. The first component shows a separation of some Bergamasca animals from the rest,

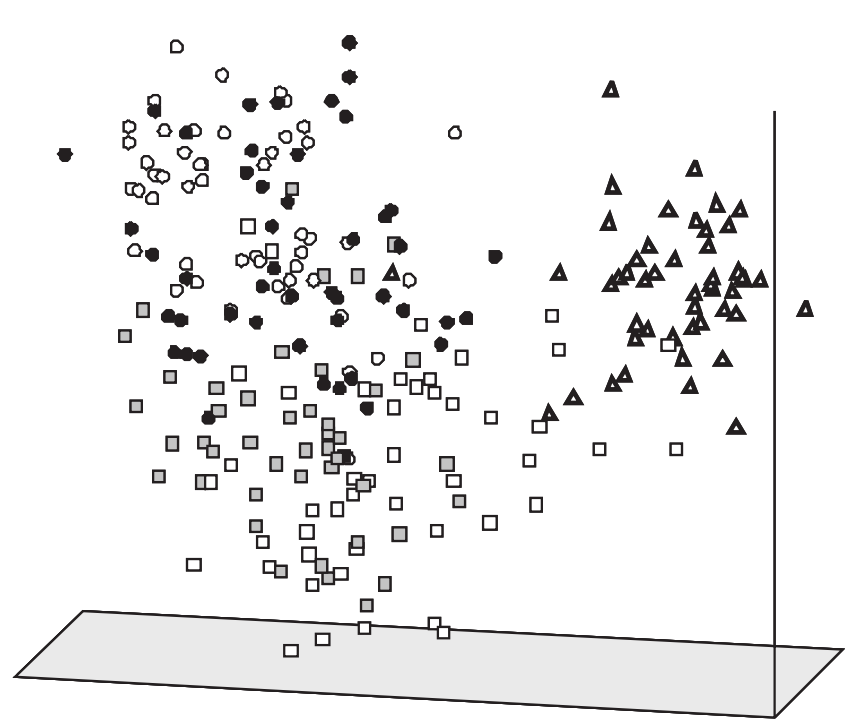

Figure 2. Principal component plot of the 238 individuals of Santa Inês (๑); Bergamasca (O); Rabo Largo ( $\square$ ) ; Morada Nova $(\square)$ and Somali $(\triangle)$ sheep populations by Jacard's coefficient. 
while the second sets the Bergamasca animals apart from the Somalis. Bergamasca and Rabo Largo animals were found to overlie the Santa Inês, instead of the Morada Nova and Somali, as expected from historical information (Morais, 2001). Here the Somali were separated from the rest, as in the earlier analyses. A degree of overlap of individuals from the different breeds was also observed, confirming earlier results of high miscegenation levels, obtained using AMOVA (Tables 4 and 5) and the dendrograms (Figure 1), or, conversely, low genetic distance between breeds.

\section{Conclusions}

1. All five breeds are significantly different from each other, although genetic variation is low.

2. Santa Inês is the result of crosses between wool and hair breeds.

3. Because they have smaller herds and significantly different genetic variability, the Somali, Rabo Largo and Morada Nova breeds should be included in the Program for Conservation of Animal Genetic Resources of Embrapa Recursos Genéticos e Biotecnologia.

\section{Acknowledgements}

To Embrapa and Finatec, for financial support; to Gilberto Leite, Hymerson Azevedo, Arturo SelaiveVillaroel, Robespierre Soares, Ana Luisa Aragão and Gisele Oliveira, for collecting some samples.

\section{References}

ALI, B.A. Genetics similarity among four breeds of sheep in Egypt detected by random amplified polymorphic DNA markers. African Journal of Biotechnology, v.2, p.194-197, 2003.

BLACK IV, W.C. PCR with arbitrary primers: approach with care. Insect Molecular Biology, v.2, p.1-6, 1993.

BOLETIM PECUÁRIO. Brazilian Breeds Encyclopedia. Disponível em: http://www.boletimpecuario.com.br. Acesso em: 23 jan. 2004.

CARDOSO, M.A.; PROVAN, J.; POWELL, W.; FERREIRA, P.C.G.; DE OLIVEIRA, D.E. High genetic differentiation among remnant populations of the endangered Caesalpinia echinata Lam. (Leguminosae-Caesalpinioideae). Molecular Ecology, v.7, p.601608, 1998.

DE QUEIROZ, K.; GOOD, D.A. Phenetic clustering in biology: a critique. The Quarterly Review of Biology, v.72, p.4-30, 1997.
FELSENSTEIN, J. PHYLIP (Phylogeny Inference Package). Version 3.5c. Seattle: University of Washington, Department of Genetics, 1993. 51p.

FUCK, B. Caracterização genética do cavalo Pantaneiro: uma contribuição para conservação da raça. 2002. 64p. Dissertação (Mestrado) - Universidade de Brasília, Brasília.

HUFF, D.R.; PEAKALL, R.; SMOUSE, P.E. RAPD variation within and among natural populations of outcrossing buffalograss [Buchloe dactyloides (Nutt.) Engelm.]. Theoretical and Applied Genetics, v.86, p.927-934, 1993.

KANTANEN, J.;VILKKI, J.; ELO, K.; MAKI-TANILA, A. Random amplified polymorphic DNA in cattle and sheep: application for detecting genetic variation. Animal Genetics, v.26, p.315-320, 1995.

LYNCH, M.; MILLIGAN, B.G. Analysis of population genetic structure with RAPD makers. Molecular Ecology, v.3, p.91-99, 1994.

MASON, I.L. Prolific tropical sheep. Italy: FAO/UNEP, 1980. 124p. (Animal production and health paper, 17).

MILLER, M.P. Tools for population genetics analyses (TFPGA): a windows program for the analysis of allozyme and molecular population genetic data 1997. Disponível em: $<$ http://herb.bio.nau.edul miller/tfpga.htm > . Acesso em: nov. 2004.

MILLER, S.A.; DYKES, D.D.; POLESKY, H.F. A simple salting out procedure for extracting DNA from human nucleated cells. Nucleic Acids Research, v.16, p.1215, 1988.

MORAIS, O.R. O melhoramento genético dos ovinos no Brasil: situação atual e perspectivas para o futuro. In: SIMPÓSIO NACIONAL DE MELHORAMENTO ANIMAL, 2000, Belo Horizonte. Anais. Belo Horizonte: FEPMVZ, 2000. p.266-272.

MORAIS, O.R. O melhoramento genético dos ovinos no Brasil. In: PEREIRA, J.C.C.(Ed.). Melhoramento genético aplicado à produção animal. 3.ed. Belo Horizonte, FEPMUZ, 2001. p.320330.

OLIVEIRA, R.R. Caracterização genética de populações de caprinos da raça Moxotó usando marcadores moleculares. 2003. 59p. Dissertação (Mestrado) - Universidade Federal da Paraíba, Areia.

RAYMOND, M.L.; ROUSSET, F. An exact test for population differentiation. Evolution, v.49, p.1280-1283, 1995.

SCHNEIDER, S.; ROESSLI, D.; EXCOFFIER, L. Arlequin version 2.000: a software for population genetic data analysis. Switzerland: University of Geneva, Genetics and Biometry Laboratory, 2000. 111 .

SERRANO, G.M.S.; EGITO, A.A.; MCMANUS, C.; MARIANTE, A.S. Genetic diversity and population structure of Brazilian native bovine breeds. Pesquisa Agropecuária Brasileira, v.39, p.543-549, 2004.

SPRITZE, A.; EGITO, A.A.; MARIANTE, A.S.; MCMANUS, C. Genetic characterization of Criollo Lageano cattle using RAPD 
markers. Pesquisa Agropecuária Brasileira, v.38, p.1157-1164, 2003.

TAPIO, M.; GRIGALIUNAITE, I. Is there a role for mitochondrial inheritance in sheep breeding? Veterinarija ir Zootechnika, v.18, p.108-111, 2002.

WEST, D.; BLACK IV, W.C. Breeding structure of three species of Snow Pool Aedes mosquito species in northern Colorado. Heredity, v.81, p.371-380, 1998.
WILLIAMS, J.G.K.; KUBELIK, A.R.; LIVAK, K.J.; RAFALSKI, J.A.; TINGEY, S.V. DNA polymorphisms amplified by arbitrary primers are useful as genetics markers. Nucleic Acids Research, v.18, p.6531-6535, 1990.

YUANFANG, G.; XIANGLONG, L.; ZHENGZHU, L.; JINQUAN, L. Studies of random amplified polymorphic DNA (RAPD) of main indigenous sheep breeds in China. Hereditas, v.24, p.423-426, 2002.

Received on May 6, 2004 and accepted on March 7, 2005 